\title{
Kedudukan Hukum Deponeering dalam Sistem Peradilan Pidana
}

\author{
Desi Ratnasari, Sahuri Lasmadi, Elly Sudarti
}

Fakultas Hukum, Universitas Jambi

Author's Email Correspondence: drsdesiratnasari21@gmail.com

\begin{abstract}
ABSTRAK
Artikel ini bertujuan untuk mengetahui dan menganalisis implikasi hukum serta menganalisis terhadap regulasi kepentingan umum sebagai syarat pelaksanaan pengesampingan perkara (deponeering) oleh Jaksa Agung demi kepentingan umum dalam prespektif perkembangan hukum acara pidana. Penelitian ini merupakan penelitian hukum, yang diperoleh dari studi perundang-undangan (statute approach), konsep (conceptual approach), kasus. Hasil dari penelitian ini adalah adanya diskriminatif terhadap equality before the law yang terdapat dalam Pasal 27 Ayat (1) Undang-Undang Dasar Negara Republik Indonesia Tahun 1945 dan dapat memicu salah tafsir oleh Jaksa Agung. Lalu di dalam pelaksanaannya belum terdapat regulasi yang jelas mengenai penerapan asas oportunitas yang berhubungan dengan kewenangan jaksa agung dalam pelaksanaan pengesampingan perkara (deponeering) demi kepentingan umum di dalam Kitab Undang-Undang Hukum acara Pidana (KUHAP).
\end{abstract}

\section{ARTICLE HISTORY}

Submission: 2021-02-09

Accepted: 2021-04-22

Publish: 2021-04-26

KEYWORDS: Criminal justice system; deponeering;legal position.

\begin{abstract}
This article aims to identify and analyze the legal implications and analyze the regulation of public interest as a condition for implementing deponeering by the Attorney General for the sake of the public interest in the perspective of the development of criminal procedural law. This research is a legal research, obtained from statutory studies (statute approach), concept (conceptual approach), cases. The result of this research is that there is discrimination against equality before the law contained in Article 27 Paragraph (1) of the 1945 Constitution of the Republic of Indonesia and can trigger misinterpretation by the Attorney General. Then in its implementation there is no clear regulation regarding the application of the opportunity principle related to the authority of the attorney general in the implementation of case waiver (deponeering) for the public interest in the Criminal Procedure Code.
\end{abstract}

\section{A. PENDAhUluAN}

Indonesia secara normatif-konstitusional adalah negara berdasarkan hukum atau yang sering juga disebut sebagai negara hukum. ${ }^{1}$ Penindakan setiap pelanggaran peraturan perundang-undangan melalui proses peradilan pidana yang menyertakan peran aparat penegak hukum yang terdiri atas Kepolisian, Kejaksaan, Pengadilan, dan Lembaga Pemasyaratakatan yang merupakan penegakan hukum. Penegakan

1 Kabib Nawawi, "Progresifitas Polisi Menuju Polisi Profesional”, Inovatif Jurnal Hukum Vol. 2, No. 3, 2010. http://online-journal.unja.ac.id/index.php/jimih/article/view/202. 
tergantung pada hubungan yang serasi antara hukum itu sendiri, penegak hukum, fasilitasnya dan masyarakat yang diaturnya yang terbentuk dalam suatu sistem peradilan pidana. Sistem peradilan pidana yang memiliki tahap yaitu, penyidikan, penuntutan, pemeriksaan di pengadilan dan pelaksanaan putusan melalui lembaga pemasyarakatan.

Asas penuntutan terdapat dua yaitu asas legalitas dan asas oportunitas (het legaliteis en het oppotuites beginsel). Asas opportunitas merupakan penuntut umum memiliki wewenang untuk menuntut maupun tidak menuntut suatu perkara beralaskan demi kepentingan umum. Sedangkan asas oportunitas bertentangan dengan asas legalitas, penuntut umum harus menuntut tindak pidana sesuai dengan peraturan yang ada atau sudah diatur.

Undang-Undang Nomor 16 Tahun 2004 Tentang Kejaksaan Republik Indonesia menjelaskan bahwa deponeering adalah tugas dan wewenang yang diberikan secara khusus untuk Jaksa Agung dalam mengesampingkan perkara demi kepentingan umum. Namun yang dimaksud dengan "kepentingan umum" tidak memiliki batasan yang jelas dan tegas sehingga pengertiannya terkesan subjektif, politis dan berindikasi multitafsir.

Jaksa Agung resmi mengenyampingkan perkara Abraham Samad dan Bambang Widjojanto demi kepentingan umum, karena kedua mantan pimpinan KPK tersebut dikenal sebagai figur yang memiliki komitmen pemberantasan korupsi. Mantan pimpinan Komisi Pemberantasan Korupsi Abraham Samad diancam dengan Pasal 263 Ayat (1) Juncto Pasal 53 Ayat (1) ke-1 KUHP sub Pasal 264 Ayat (1) Juncto Pasal 55 Ayat (1) KUHP dan penyalahgunaan kekuasaan diancam Pasal 36 Juncto Pasal 65 Undang-Undang Nomor 30 Tahun 2002 Tentang Komisi Pemberantasan Korupsi terkait pemalsuan dokumen, sedangkan Bambang Widjojanto yang terjerat kasus mempengaruhi saksi untuk memberikan keterangan palsu saat sidang sengketa Pilkada Kotawaringin Barat, Kalimantan Tengah di Mahkamah Konstitusi pada 2010 diancam dengan Pasal 242 Juncto Pasal 55 KUHP dan Pasal 56 KUHP.

Pengesampingan Perkara dimana suatu perkara sudah cukup bukti untuk diajukan di muka sidang pengadilan, namun perkaranya di kesampingkan dan tidak dilimpahkan ke pengadilan oleh penuntut umum demi "kepentingan umum". Pengesampingan perkara dengan istilah lain deponeering ini akan membawa dampak bagi hukum, baik terhadap proses peradilan terlebih lagi kepada elemen-elemen yang melaksanakan suatu proses peradilan tersebut. Dampak negative adanya pengesampingan perkara akan menimbulkan kekhawatiran akan proses yang tidak transparan.

Penjelasan Pasal 35 huruf c Undang-Undang Nomor 16 Tahun 2004 Tentang Kejaksaan Republik Indonesia menyatatakan, yang dimaksud "kepentingan umum adalah kepentingan bangsa dan atau kepentingan masyarakat luas. Mengesampingkan perkara asas oportunitas, yang hanya dapat dilakukan oleh Jaksa Agung setelah memperhatikan saran dan pendapat dari badan-badan kekuasaan negara yang mempunyai hubungan dengan masalah tersebut".

Makna kepentingan umum disini belum jelas karena hanya ditafsirkan oleh Jaksa Agung, hal ini dapat mengakibatkan penegakkan hukum dikorbankan demi kepentingan umum. Dimana di Indonesia juga dikenal dengan persamaan dihadapan hukum (equality before the law) diatur di Pasal 27 Ayat (1) Undang-Undang Dasar Negara Republik Indonesia Tahun 1965 yang menyatakan "Segala warga negara 
bersamaan kedudukannya dalam hukum dan pemerintahan wajib menjunjung hukum dan pemerintahan itu sendiri dengan tidak ada kecualinya".

Kepentingan umum yang tidak jelas dapat menimbulkan masalah penegakan hukum, karena sebagai akibat ketidak jelasan atau kurang jelasnya suatu ketentuan peraturan yang terdapat suatu peraturan perundang-undangan sehingga dapat mengakibatkan penyalahgunaan dalam pelaksanaanya. Perlu pengaturan yang secara jelas kriteria kepentingan umum bagi Jaksa Agung dalam mengesampingkan perkara sebagai pedoman Jaksa Agung dalam menjalankan asas oportunitas.

\section{B. METODE PENELITIAN}

Penelitian ini menggunakan Penelitian Hukum, yang diperoleh dari studi perundang-undangan (statute approach), studi konsep (conceptual approach), studi kasus (case approach), mengkaji dan menganalisa semua peraturan perundangundangan yang berkaitan, kedudukan hukum tentang Deponeering dalam Sistem Peradilan Pidana, baik Undang-Undang maupun peraturan perundangan lainnya.

\section{PEMBAHASAN}

1. Implikasi Hukum Terhadap Regulasi Kepentingan Umum Sebagai Syarat Pelaksanaan Pengesampingan Perkara (Deponeering) Oleh Jaksa Agung

Indonesia jarang sekali melaksanakan pengesampingan perkara (deponeering) walau sudah diatur dalam Pasal 35 huruf c Undang-Undang Nomor 16 Tahun 2004 Tentang Kejaksaan Republik Indonesia merupakan pelaksanaan dari asas oportunitas yang dimiliki Jaksa Agung untuk mengesampingakan suatu perkara demi "kepentingan umum".

Tindakan untuk tidak menuntut karena alasan kebijakan Jaksa Agung diperbolehkan mengesampingkan perkara sekalipun buktinya cukup dan sudah dapat dilimpahkan dalam sidang pengadilan, namun perkara yang sudah siap disidangkan tidak dilakukan sidang. ${ }^{2}$ Pengesampingan perkara (deponeering) banyak terdapat pro dan kontra sendiri di dalam masyarakat dan dikalangan akademisi, karena pengesampingan perkara (deponeering) sendiri dianggap diskriminatif terhadap prinsip-prinsip hukum seperti, kepastian hukum, dan bertentangan terhadap persamaan dihadapan hukum (equality before the law) yang diamanatkan oleh Pasal 27 Ayat (1) Undang-Undang Dasar Republik Indonesia Tahun 1945 yang menyatakan bahwa "segala warga Negara bersamaan kedudukkannya di dalam hukum dan pemerintahan dan wajib menjunjung hukum dan pemerintahan itu dengan tidak ada kecualinya".

Pelaksanaan pengesampingan perkara (deponeering) berdasarkan kepentingan umum, dan dapat dilihat kepentingan umum dalam penjelasan Pasal 35 huruf c undang-Undang Nomor 16 Tahun 2004 Tentang Kejaksaan Republik Indonesia menyatakan bahwa:

Yang dimaksud "kepentingan umum" adalah kepentingan bangsa dan/atau kepentingan masyarakat luas. Mengesampingkan perkara sebagaimana dimaksud dalam ketentuan ini merupakan pelaksanaan asas oportunitas, yang hanya dapat dilakukan oleh Jaksa Agung setelah memperhatikan saran dan

2 M. Yahya Harahap, Pembahasan Permasalahan dan Penerapan KUHAP Penyidikan dan Penuntutan, Sinar Grafika, Jakarta, 2018, hlm. 436. 
pendapat dari badan-badan kekuasaan negara yang mempunyai hubungan dengan masalah tersebut.

Konsep kepentingan umum dalam peaksanaan pengesampingan perkara saat di terapkan dalam suatu perkara maka timbul pertanyaan disetiap individu bagaimana Jaksa Agung menafsirkan kepentingan umum untuk diterapkan didalam suatu perkara sedangkan kriteria kepentingan umum tidak jelas. Apa yang menjadi syarat formal dalam pelaksanaan asas oportunitas ini, karena pengertian kepentingan umum itu sendiri tidak ada persamaan atau dapat dikatakan sangat beragam dari doktrin maupun dalam peraturan perundang-undangan sehingga untuk pengertian kepentingan umum ini menjadi multi tafsir.

Jaksa Agung resmi mengesampingkan perkara Abraham Samad dan Bambang Widjojanto demi kepntingan umum, karena kedua mantan pimpinan kedua KPK tersebut dikenal luas sebagai figur yang memiliki komitmen pemberantasan korupsi kepada kedua mantan pimpinan Komisi Pemberantasan Korupsi Abraham Samad terkait pemalsuan dokumen yang diancam dengan Pasal 263 Ayat (1) Juncto Pasal 53 Ayat (1) ke-1 KUHP sub Pasal 264 Ayat (1) Juncto Pasal 55 Ayat (1) KUHP dan penyalahgunaan kekuasaan diancam Pasal 36 Juncto Pasal 65 Undang-Undang Nomor 30 Tahun 2002 Tentang Komisi Pemberantasan Korupsi. Dan Bambang Widjojanto terjerat kasus mempengaruhi saksi untuk memberikan keterangan palsu saat sidang sengketa Pilkada Kota Waringin Barat Kalimantan Tengah di Mahkamah Konstitusi pada 2010 diancam Pasal 242 Juncto Pasal 55 KUHP dan Pasal 56 KUHP.

Pemberian keputusan deponeering menjadi perdebatan di Indonesia baik dikalangan akademisi maupun di antar lembaga negara. Perdebatan terjadi karena beragamnya pendapat atau dapat dikatakan bahwa untuk multitafsir terhadap pengertian "kepentingan umum" untuk diterapkan dalam suatu perkara. Seharusnya hal ini tidak boleh terjadi karena menggangu keharmonisan antar lembaga negara.

Perlu adanya pengaturan lebih jelas sejauh mana batasan-batasan kepentingan umum yang meliputi kepentingan bangsa, kepentingan negara, dan atau kepentingan masyarakat sehingga dapat tercipta keadilan, kemanfaatan dan terutama kepastian hukum. Jaksa agung dalam melakukan pengesampingan perkara haruslah hati-hati dalam menafsirkan kepentingan umum setelah meminta saran dan pendapat dari badan kekuasaan negara. Agar tidak terjadi penyalahgunaan wewenang.

Norma yang baik mengandung tiga asas diantaranya asas kepastian hukum, asas kemanfaatan, dan asas keadilan. Dimana asas kepatian hukum Menurut Sudikno Mertokusumo menyatakan kepastian hukum merupakan perlindungan yustisiabel terhadap tindakan sewenang-wenang, yang berarti bahwa seseorang akan memperoleh sesuatu yang diharapkan dalam keadaan tertentu. ${ }^{3}$ Kemudian asas kemanfaatan merupakan optimalisasi dari tujuan sosial dari hukum, setiap hukum di samping dimaksudkan untuk mewujudkan ketertiban dan keteraturan sebagai tujuan akhir, tetapi juga mempunyai tujuan sosial tertentu, yaitu kepentingan yang diinginkan untuk diwujudkan masyarakat dari negara. ${ }^{4}$ Menurut Sudikno Mertokusumo

3 Ahmad Rifai, Penemuan Hukum oleh Hakim dalam Prespektif Hukum Progresif, Sinar Grafika, Jakarta, 2011, hlm. 115.

4 Margono, Asas Keadilan, Kemanfaatan \& Kepastian Hukum dalam Putusan Hakim, Sinar Grafika, Jakarta, 2019, hlm. 111. 
mengartikan keadilan sebagai penilaian terhadap perlakuan seseorang terhadap yang lainnya dengan menggunakan normatertentu sebagai ukurannya. ${ }^{5}$

Pengesampingan perkara atau dengan istilah lain deponeering berbeda dengan penghentian penuntutan karena deponeering merupakan wewenang yang dimiliki Jaksa Agung untuk mengesampingkan perkara yang sudah cukup bukti. Penulis berpendapat bahwa konsep kepentingan umum yang ada di Pasal 35 huruf c UndangUndang Nomor 16 Tahun 2004 Tentang Kejaksaan Republik Indonesia bersifat abstrak dan tidak konkret sehingga merupakan kewenangan penuh Jaksa Agung untuk menafsirkan pengertian kepentingan umum untuk diterapkan didalam suatu perkara.

Pengesampingan perkara atau deponeering seharusnya dapat juga dilakukan terhadap kasus yang kecil, karena dalam konsep kepentingan umum sendiri tidak dijelaskan perkara apa saja yang dapat dikesampingkan, namun hal ini tidak dilakukan. Jika Indonesia memiliki pedoman (guildlines) seperti halnya Netherland lebih jelas lagi perkara seperti apa saja yang dapat dilakukan pengesampingan perkara salah satunya perkara dilakukan oleh lanjut usia. Maka pengesampingan perkara tidak akan mencedarai hukum sendiri terutama terhadap prinsip hukum equality before the law.

Belanda boleh memutuskan akan menuntut atau tidak menuntut perkara dengan atau tanpa syarat. Wewenang tersebut di dasarkan atas tiga hal. Pertama, dakwaan dicabut karena alasan kebijakan (antara lain, tindak pidananya tidak seberapa, pelakunya sudah tua, dan kerugian sudah diganti. Kedua, perkara dikesampingkan karena alasan teknis (biasanya lebih dari 50 persen karena buktinya kurang. Ketiga melalui penggabungan, yaitu menggabungkan perkara tersangka dengan perkaranya yang sudah diajukan ke pengadilan 6 .

Pengesampingan perkara (deponeering), perlu penyesuaian mengenai penerapan deponeering di Indonesia. Di Belanda telah terjadi modifikasi sedemikian rupa mengenai deponeering ini. Belanda telah lebih dulu memperluas penerapan deponeering yang sama-sama berdasarkan asas oportunitas dengan ketentuan baru, bahwa semua perkara yang acaman pidananya dibawah 6 (enam) tahun penjara dapat afdoening (penyelesaian perkara di luar pengadilan), tetapi hanya perkara ringan saja. Penyelesaian perkara berdasarkan asas oportunitas dengan cara mengenakan denda administratif, sehingga dapat menambah pendapatan negara, mengurangi jumlah perkara di pengadilan dan mengurangi jumlah narapidana.

Jaksa penuntut umum menuntut kakek Samirin berusia 69 tahun 10 bulan penjara melanggar Pasal 107 huruf d Undang-Undang Nomor 39 Tahun 2014 Tentang Perkebunan yang diduga mengutip atau memungut hasil panen perkebunan PT. Bridgestone seberat 1,9 kilo gram jika di rupiahkan seharga Rp. 17.480. Pengadilan Simalungun memutuskan, menyatakan Samirin terbukti secara sah dan meyakinkan bersalah melakukan tindak pidana secara tidak sah memanen dan atau memungut hasil perkebunan sebagaimana dalam dakwaan alternatif kedua. Menjatuhkan pidana kepada terdakwa dengan pidana penjara 2 bulan 4 hari. $^{7}$

5 Ibid., hlm. 105.

6 https://globa24jam.com/2020/01/12/kasus-hukum-kakek-samirin-diusia-senja-19kilogram-karet-dituntut-10-bulan-ditahan/ . Diakses pada tanggal 27 Januari 2020.

7 https://m.detik.com/news/berita/d-4862699/kakek-samirin-pungut-sisa-getah-karet-rp17-ribu-di-hukum-2-bulan-penjara-adilkah/3. Diakses pada tanggal 27 Januari 2020. 
Kasus kakek Samirin mencuri banyak perhatian bagi pakar hukum pidana. Pakar hukum pidana berpendapat bahwa seharusnya kasus perkara kecil yang dilakukan oleh lanjut usia dikesampingkan demi kepentingan umum. Pakar hukum pidana Asep Iwan Irawan berpendapat bahwa fakta kasus pencurian kakek Samirin kasus pencurian biasa dan seharusnya dikenakan Pasal di KUHP bukan Undang-Undang Nomor 39 Tahun 2014 Tentang Perkebunan dan jika menggunakan Pasal di KUHP kasus kakek Samirin tidak boleh diproses sesuai dengan Peraturan Makamah Agung Republik Indonesia Nomor 2 Tahun 2002 Tentang Penyesuaian Batas Tindak Pidana Ringan dan Jumlah Denda Dalam KUHP karena jumlah yang dicuri kurang dari Rp.2.500.000,-..$^{8}$ Sesuai dengan konsep kepentingan umum yang dapat dilakukan pengesampingan perkara menurut J. M. Van. Bemmelen bahwa:

Bila kepentingan pribadi menghendaki tidak dilakukannya penuntutan ialah persoalan hanya perkara kecil, dan atau jika yang melakukan tindak pidana telah membayar kerugian dan dalam keadaan ini masyarakat tidak mempunyai kepentingan dengan penuntutan atau hukuman. Penyampingan perkara yang dilakukan demi kepentingan pribadi dapat merugikan, bahwa ada kalanya sudah terang benderang seseorang melakukan suatu kejahatan, akan tetapi keadaan yang nyata adaah sedemikian rupa, sehingga kalau seseorang dituntut di muka hakim pidana, kepentingan negara sangat dirugikan. ${ }^{9}$

Tidak hanya kakek Samirin saja lanjut usia yang harus dihukum dan diproses sampai pengadilan kasus perkara pidanananya, namun masih ada beberapa kasus lagi yang menimpa lanjut usia untu menjalani proses hukum acara pidana di persidangan. Namun dapat dilihat juga dengan kasus Nenek Minah yang sama-sama dengan kasus Kakek Samirin bahwa melakukan pencurian atau memungut hasil perkebunan, namun Nenek Minah dituntut dengan Pasal 362 KUHP bukan Undang-Undang Nomor 39 Tahun 2014 Tentang Perkebunan.

Pengesampingan perkara dapat berimplikasi terhadap pencari keadilan yaitu pihak yang di deponeering dan masyarakat pada umumnya. Untuk pihak yang di deponeering atau perkaranya yang dilakukan pengesampingan terdaapt pro dan kontra mengenai apakah status tersangka bagi pihak yang di deponeering hilang atau tetap berstatus tersangka karena tidak ada pengaturannya. Deponeering atau dengan istilah lainnya pengesampingan perkara sudah final dan sah karena deponeering merupakan wewenang yang diberikan oleh Pasal 35 huruf c Undang-Undang Nomor 16 Tahun 2004 Tentang Kejaksaan Republik Indonesia kepada Jaksa Agung dan tidak ada pengaturan upaya yang dapat dilakukan untuk menguji kembali perkara yang telah dikesampingkan oleh Jaksa Agung berbeda dengan penghentian penuntutan yang dapat dilakukan upaya praperadilan dikemudian hari.

Impilkasi regulasi kepentingan umum sebagai syarat pelaksanaan pengesampingan perkara (deponeering) oleh Jaksa Agung bagi masyarakat umum lainnya terjadi diskriminatif terhadap equality before the law yang terdapat dalam Pasal 27 Ayat (1) Undang-Undang Dasar Republik Indonesia Tahun 1945 yang

8 https://www.tribunews.com/nasional/2020/01/23/tanggapi-kasus-kakek-samirin-curigetah-karet-pakar-hukum-di-mata-hukum-semua-sama. Diakses pada tanngal 15 Februari $\underline{2020 .}$

9 Ibid. 
menyatakan bahwa "segala warga negara bersamaan kedudukannya di dalam hukum dan pemerintahan dan wajib menjunjung hukum dan pemerintahan itu dengan tidak ada kecualinya" dan dapat menyebabkan salah tafsir oleh Jaksa Agung dan timbul penafsiran yang beragam dapat merugikan para pencari keadilan.

\section{Regulasi Terhadap Penerapan Asas Oportunitas yang Berhubungan dengan Kewenangan Jaksa Agung dalam Pelaksanaan Pengesampingan Perkara (Deponeering) Demi Kepentingan Umum dalam Prespektif Perkembangan Hukum Acara Pidana.}

Hukum acara pidana memiliki tujuan untuk mencari dan mendapatkan atau setidak-tidaknya mendekati kebenaran material, ialah kebenaran yang selengkaplengkapnya dari suatu perkara pidana dengan menerapkan ketentuan hukum acara pidana secara jujur dan tepat dengan tujuan untuk mencari siapakah pelaku yang didakwakan melakukan suatu pelanggaran hukum. ${ }^{10}$ Meminta putusan pemeriksaan dan putusan dari pengadilan guna menemukan apakah terbukti bahwa suatu tindak pidana telah dilakukan dan apakah orang yang didakwa itu bersalah.

Pengesampingan perkara (deponeering) yang merupakan pengesampingan perkara karena suatu kebijakan yang merupaka wewenang yang dimiliki oleh Jaksa Agung dapat dilihat juga terkait dengan Pasal 46 Ayat (1) huruf c Kitab Undang-Undang Hukum Acara Pidana (KUHAP) yang menyatakan bahwa:

Benda yang dikenakan penyitaan dikembalikan kepada orang atau kepada mereka dari siapa benda itu disita, atau kepada orang atau kepada mereka yang paling berhak, apabila:

c. Perkara tersebut dikesampingkan untuk kepentingan untuk kepentingan umum atau perkara tersebut ditutup demi hukum, kecuali apabila benda itu diperoleh dari suatu tindak pidana atau yang dipergunakan untuk melakukan suatu tindak pidana.

Wewenang pengesampingan perkara atau dengan istilah lain deponeering jarang sekali digunakan oleh Jaksa Agung, asas oportunitas ini sudah lama diterapkan di Indonesia. Dalam KUHAP wewenang tersebut tidak dirumuskan secara eksplisit, namun keberadaan wewenang Jaksa Agung diakui terdapat secara tersirat di dalam Kitab Undang-Undang Hukum Acara Pidana (KUHAP) di penjelasan Pasal 77 yang menyatakan bahwa: "Yang dimaksud dengan "penghentian penuntutan" tidak termasuk pengesampingan perkara untuk kepentingan umum yang menjadi wewenang Jaksa Agung".

Pelaksanaan asas oportunitas juga diatur dalam Pasal 1 Ayat (1) dan Ayat (2); Pasal 30 ayat (1) huruf a dan huruf b; dan Pasal 35 huruf c Undang-Undang Nomor 16 Tahun 2004 Tentang Kejaksaan Republik Indonesia. Pasal 1 Ayat (1) dan Ayat (2) meyatakan bahwa:

10 Andi Hamzah, Pengantar Hukum Acara Pidana Indonesia, Ghalia Indonesia, Jakarta, 1990, hlm. 18. 
(1) Jaksa adalah pejabat fungsional yang diberi wewenang oleh undang-undang ini untuk bertindak sebagai penuntut umum dan pelaksanaan putusan pengadilan yang telah memperoleh kekuatan hukum serta wewenang lain berdasarkan undang-undang.

(2) Penuntut umum adalah jaksa yang diberi wewenang oleh undang-undang ini untuk melakukan penuntutan dan melaksanakan penetapan hakim.

Undang-Undang Nomor 16 Tahun 2004 Tentang Kejaksaan Republik Indonesia Pasal 30 ayat (1) huruf a dan huruf b menyatakan bahwa:

(1) Di bidang pidana, kejaksaan mempunyai tugas dan wewenang;

a. Melakukan penuntutan;

b. Melaksanakan penetapan hakim dan putusan pengadilan yang telah memperoleh kekuatan hukum tetap.

Undang-Undang Nomor 16 Tahun 2004 Tentang Kejaksaan Republik Indonesia Pasal 30 Ayat (1) huruf a dan huruf b menyatakan bahwa Jaksa Agung mempunyai tugas dan wewenang mengesampingkan perkara demi kepentingan umum. Dalam penjelasan Pasal 35 huruf c menyatakan bahwa:

Yang dimaksud "kepentingan umum" adalah kepentingan bangsa dan/atau kepentingan masyarakat luas. Mengesampingkan perkara sebagaimana dimaksud dalam ketentuan ini merupakan pelaksanaan asas oportunitas, yang hanya dapat dilakukan oleh Jaksa Agung setelah memperhatikan saran dan pendapat dari badan-badan kekuasaan negara yang mempunyai hubungan dengan masalah tersebut.

Wewenang khusus untuk melakukan penuntutan pidana ke pengadilan diberikan kepada Jaksa Selaku Penuntut Umum. Dalam Pasal 1 Ayat (6) huruf a Kitab UndangUndang Hukum Acara Pidana (KUHAP) menyatakan bahwa: "Jaksa adalah pejabat yang diberi wewenang oleh undang-undang untuk bertindak sebagai penuntut umum serta melaksanakan penetapan hakim. Wewenang ini diberikan oleh undang-undang kepada Jaksa Selaku Penuntut Umum.

Penghentian penuntutan termaksud dalam wewenang jaksa selaku penuntut umum sebagaimana tercantum dalam Kitab Undang-Undang Hukum Acara Pidana (KUHAP) pada Pasal 14 huruf h yang menyatakan bahwa "Menutup Perkara Demi Kepentingan Hukum". Hasil penyidikan yang jelas sudah dinyatakan oleh jaksa selaku penuntut umum sudah lengkap, telah memenuhi unsur-unsur yang akan didakwakan dan bisa langsung dilimpahkan, akan tetapi dalam pelaksanaannya hasil penyidikan sudah maksimum jaksa selaku penuntut umum telah mengirimkan petunjuk-petunjuk pada penyidik untuk melengkapinya akan tetapi tidak ditemukan unsur-unsurnya.

Pengesampingan Perkara atau yang dikenal deponeering , perkaranya memang sudah cukup bukti dan alasan untuk diajukan di muka sidang pengadilan. Dari fakta dan bukti yang ada, kemungkinan besar terdakwa dapat dijatuhi hukuman. Akan tetapi perkara yang cukup fakta dan bukti ini sengaja di kesampingkan dan tidak dilimpahkan ke pengadilan oleh penuntut umum demi "kepentingan umum".

Penghentian penuntutan alasan bukan didasarkan kepada kepentingan umum, akan tetapi semata-mata didasarkan kepada alasan dan kepentingan hukum itu sendiri yaitu: 
1. Perkara yang bersangkutan "tidak" mempunyai pembuktian yang cukup, sehingga jika perkaranya diajukan ke pemeriksaan siding pengadilan diduga keras terdakwa akan dibebaskan oleh hakim, atas alasan yang didakwakan tidak terbukti.

2. Apa yang dituduh kepada terdakwa bukan merupakan tindak kejahatan atau pelanggaran.

3. Penghentian penuntutan atas dasar perkara ditutup demi hukum ialah tindak pidana yang didakwanya oleh hukum itu sendiri telah dibebaskan dari tuntutan atau dakwaan dan perkara oleh hukum sendiri harus dhentikan pemeriksaanya, antara lain:

a. Karena tersangka/terdakwa meninggal dunia

b. Atas alasan nebis in idem

c. Perkara kedaluwarsa.

Selain diatur dalam Undang-Undang Nomor 8 Tahun 1981 Tentang Kitab Undang-Undang Hukum Acara Pidana (KUHAP). Pengaturan asas oportunitas yang berkaitan dengan pengesampingan perkara demi kepentingan umum oleh lembaga Kejaksaan Republik Indonesia diantara lain: Pasal 8 Undang-Undang Nomor 15 Tahun 1961 Tentang Ketentuan-Ketentuan Pokok Kejaksaan Republik Indonesia, Pasal 32 huruf c Undang-Undang Nomor 5 Tahun 1991 Tentang Kejaksaan Republik Indonesia, dan Pasal 35 huruf c Undang-Undang Nomor 16 Tahun 2004 Tentang Kejaksaan Republik Indonesia.

Konsideran dalam KUHAP jelas dinyatakan menganut asas legalitas, akan tetapi masih mengakui asas oportunitas. Dengan demikian keadaan ini mengakibatkan pertentangan dan "dualistis" dalam pelaksanaan KUHAP. Di satu sisi dengan tegas mengakui "asas legalitas", tetapi pada sisi lain asas legalitas itu tidak diindahkan oleh kenyataan pengakuan KUHAP itu sendiri akan eksistensi keberadaan asas oportunitas. Sedangkan konsep "kepentingan umum" sangat kabur dan multitafsir, karena KUHAP sendiri tidak merinci secara tegas kriteria kepentingan umum, sehingga dalam praktek penafsiran baru yang sesuai dengan kepentingan zaman. Makna harfiah tentang oprtunitas adalah ketepatan, kepantasan, menguntungkan, saat yang tepat, layak, kesempatan dan manfaat yang baik. Jelas sekali bahwa asas ini tiada lain untuk memberikan kemanfaatan, kelayakan dan kesempatan yang baik, guna kepentingan masyarakat.

Asas oportunitas merupakan wewenang Jaksa Agung untuk mengenyampingkan perkara dan tidak menuntut ke pengadilan walaupun telah memenuhi standar alat bukti untuk dilakukan penututan dengan dasar pertimbangan kepentingan umum. Asas oportunitas lebih merupakan suatu kebijaksanaan yang memberi wewenang kepada Jaksa Agung untuk memotong salah satu mata rantai proses peradilan. Jaksa Agung punya kewenangan untuk memotong salah satu proses peradilan mulai dari proses penuntutan-pemeriksaan di muka pengadilan dan pelaksanaan putusan pengadilan (eksekusi) dengan tujuan kepentingan umum. Yang dimaksud dengan kepentingan umum adalah termasuk kepentingan Negara yang tercermin dalam pelaksanaan tugas dan wewenang lembaga-lembaga Negara. Sedangkan kepentingan masyarakat tercermin dalam hukum yang hidup dalam masyarakat.

\section{SIMPULAN}

Implikasi hukum terhadap regulasi kepentingan publik sebagai syarat pelaksanaan pengenyampingan perkara (deponeering) oleh Jaksa Agung terjadi 
diskriminatif terhadap equality before the law yang terdapat dalam Pasal 27 Ayat (1) Undang-Undang Dasar Republik Indonesia Tahun 1945 yang menyatakan bahwa "segala warga negara bersamaan kedudukannya di dalam hukum dan pemerintahan dan wajib menjunjung hukum dan pemerintahan itu dengan tidak ada kecualinya" dan dapat menyebabkan multitafsir oleh Jaksa yang akan merugikan para pencari keadilan. Regulasi penerapan asas oportunitas yang berhubungan dengan kewenangan jaksa agung dalam pelaksanaan pengesampingan perkara (deponeering) demi kepentingan publik dalam perspektif perkembangan hukum acara pidana sudah diatur namun belum terdapat regulasi yang jelas mengenai penerapan asas oportunitas yang berhubungan dengan kewenangan Jaksa Agung dalam pelaksanaan pengesampingan perkara (deponeering) demi kepentingan umum di dalam Kitab Undang-Undang Hukum acara Pidana (KUHAP), penerapan deponeering diakui dalam KUHAP terdapat dalam penjelasan Pasal 77 KUHAP dan Pasal 46 Ayat (1) KUHAP namun hanya diatur secara tersirat. Penghentian penuntutan demi kepentingan hukum yang diatur secara jelas di dalam Tentang Kitab Undang-Undang Hukum acara Pidana (KUHAP). Pengesampingan perkara (deponeering) pengaturannya terdapat di dalam Pasal 35 huruf c Undang-Undang Nomor 16 Tahun 2004 Tentang Kejaksaan Republik Indonesia yang menyatakan bahwa Jaksa Agung mempunyai tugas dan wewenang mengenyampingkan perkara demi kepentingan umum.

\section{DAFTAR PUSTAKA}

\section{Dokumen Hukum}

Undang-Undang Dasar Negara Republik Indonesia Tahun 1945.

Republik Indonesia, Undang-Undang Tentang Hukum Pidana. Undang-Undang Nomor 1 Tahun 1946.

, Undang-Undang Tentang Hukum Acara Pidana. Undang-Undang Nomor 8 Tahun 1981. LNRI Tahun 1981 Nomor 76, TLNRI Nomor 3209.

Undang-Undang Tentang Kejaksaan. Undang-Undang Nomor 16 Tahun 2004.LNRI Ttahun 2004 Nomor 67, TLNRI Nomor 4401.

Undang-Undang Tentang Kekuasaan Kehakiman. Undang-Undang Nomor 48 Tahun 2009.LNRI Tahun 2009 Nomor 157, TLNRI Nomor 5076.

\section{Buku}

Arief, Barda Nawawi. Masalah Penegakan Hukum dan Kebijakan Hukum Pidana dalam Penanggulangan Kejahatan. Jakarta: Penerbit Buku Kencana Presada Media Group, 2007.

Bungai Rampai Kebijakan Hukum Pidana: (Perkembangan Penyusunan Konsep KUHP Baru). Jakarrta: Penerbit Buku Prenada Media Group, 2011.

Atmasasmita, Romli. Sistem Peradilan Pidana Kontemporer. Jakarta: Penerbit Buku Kencana Prenanda Media Grup, 2010. 
Hamzah, Andi. Pengantar Hukum Acara Pidana Indonesia. Jakarta: Penerbit Buku Ghalia Indonesia, 1990.

. Bunga Rampai Hukum Pidana Dan Acara Pidana, Jakarta: Penerbit Buku Ghalia Indonesia, 1986.

. Hukum Acara Indonesia. Edisi Kedua, Jakarta: Penerbit Buku Sinar Garfika, 2014.

Harahap, M. Yahya. Pembahasan Permasalahan dan Penerapan KUHAP Penyidikan dan Penuntutan. Jakarta: Penerbit Buku Sinar Grafika, 2018.

Husin, Kadri dan Budi Rizki Husin. Sistem Peradilan Pidana di Indonesia. Jakarta: Penerbit Buku Sinar Grafika, 2016.

Kaligis, O.C. Deponeering Teori dan Praktek. Bandung: Penerbit Buku PT. Alumni, 2011.

Kansil, Critine.S.T. Pengantar Ilmu Hukum Dan Tata Hukum Indonesia Jilid I. Jakarta: Penerbit Buku Balai Pustaka, 2008.

Margono. Asas Keadilan, Kemanfaatan \& Kepastian Hukum dalam Putusan Hakim. Jakarta: Penerbit Buku Sinar Grafika, 2019.

Marzuki, Peter. Penelitian Hukum. Edisi Revisi. Jakarta: Penerbit Buku Kencana, 2017

Nasution, Bahder Johan. Metode Penelitian Hukum. Bandung: Penerbit Buku Mandar Maju, 2008.

Prakoso, Djoko. Tugas Dan Peran Jaksa Dalam Pembangunan. Jakarta: Penerbit Buku Ghalia Indonesia, 1986.

. Surat Dakwaan, Tuntutan Pidana, Dan Eksaminasi Perkara Di Dalam Proses Pidana. Yogyakarta: Penerbit Buku Liberty, 1989.

Rifai, Ahmad. Penemuan Hukum oleh Hakim dalam Prespektif Hukum Progresif. Jakarta: Penerbit Buku Sinar Grafika, 2011.

Soekanto, Soerjono. Pokok-Pokok Sosiologi Hukum. Jakarta: Penerbit Buku Rajawali Pers, 2014.

Sugiarto, Umar Said. Pengantar Hukum Indonesia. Jakarta: Penerbit Buku Sinar Grafika, 2016.

Surachman dan Andi Hamzah. Jaksa Di Berbagai Negara (Peranan dan Kedudukannya. Jakarta: Penerbit Buku Sinar Grafika, 1994.

Jurnal

Ali, Mahrus, "Sistem Peradilan Pidana Progresif; Alternatif dalam Penegakan Hukum Pidana”, Ius Quia Iustum Jurnal, Vol. 14, No. 2, April (2007). https://journal.uii.ac.id/IUSTUM/article/view/1064.

Arfa, Nyimas, "Penegakan Hukum Pidana Terhadap Pelaku Tindak Pidana Dumpling Limbah ke Media Lingkungan Hidup Tanpa Izin di Wilayah Hukum Pengadilan 
Negeri Muara Bulian", Jurnal Sains Sosio Humaniora, Vol. 3, No. 1, (2019). https://online-journal.unja.ac.id/ISSH/article/view/7139.

Chali, Sri Mulyati l, "Pengesampingan Perkara (Deponering) oleh Jaksa Agung”, Wacana Paramata Jurnal Ilmu Hukum, Vol. 15, No. 1, (2016). http://paramarta.web.id/index.php/paramarta/article/view/15.

Hafrida, "Kebijakan Hukum Pidana Terhadap Pengguna Narkotika Sebagai Korban Bukan Pelaku Tindak Pidana: Studi Lapangan Daerah Jambi", Padjadjaran Journal Of Law, Vol. 3, No. 1, (2016). http://jurnal.unpad.ac.id/pjih/article/view/9337.

Hairi, Prianter Jaya, "Pengesampingan Perkara Pidana Abraham Samad Dan Bambang Wijojanto", Jurnal Info Singkat Hukum, Vol. 8, No. 4, (2016). https://google.com/search?q=prianter+jaya+hairi+pengesampinga+perkara\& $\underline{\text { ie}=u t f-8 \& o e=u t f-8 \& \text { client=firefox-b. }}$.

Hasan Damiri, "Diskresi Seponering dalam Prespektif Hukum Islam: Studi Kasus Pidana Korupsi Bibit Samad Rianto dan Chandra Martha Hamzah", Jurnal Intizihar, Vol. 22, No.1, (2016). http://jurnal.radenfatah.ac.id/index.php/intizar/article/view/544.

Kurnianto, Diska, dkk, "Pelaksanaan Deponeering Dalam Prespektif Asas Equality Before The Law", Jurnal Fakultas Hukum Universitas Muhammadiyah $\begin{array}{lllll}\text { Magelang, Vol. 13, No. } & \text { 13 }\end{array}$ htp://journal.ummgl.ac.id/index.php/variajusticia/article/download.

Lasmadi, Sahuri, "Tumpang Tindih Penyidikan pada Tindak Pidana Korupsi dalam Perspektif Sistem Peradilan Pidana", Inovatif Jurnal Ilmu Hukum Vol. 2, No. 3, (2010). https://online-journal.unja.ac.id/jimih/article/view/200.

Lasmadi, Sahuri, dkk, "Penyuluhan Hukum Kepada Masyarakat Desa Lopak Aur Kecamatan Pemayung Tentang Hukum Acara Pidana Untuk Mencegah Upaya Paksa Sewenang-wenang Oleh Aparat Penegak Hukum", Jurnal Karya Abdi Masyarakat, Vol. 3, No. 2, (2019). https://www.onlinejournal.unja.ac.id/JKAM/article/view/8487.

Nawawi, Kabib, "Progresifitas Polisi Menuju Polisis Profesional", Inovatif Jurnal Ilmu Hukum, Vol. 2, No. 3, (2010). http://onlinejournal.unja.ac.id/index.php/jimih/article/view/202.

Usman dan Andi Najemi, "Mediasi Penal di Indonesia: Keadilan, Kemanfaatan, dan Kepastian Hukumnya", Undang Jurnal hukum Universitas Jambi, Vol. 1, No. 1, (2018). http://ujh.unja.ac.id/index/php/home/article/view/17/4.

Yasin, M. Al. Arif, "Penegakan Hukum dalam Prespektif Hukum Progresif", Undang $\begin{array}{lllll}\text { Jurnal Hukum, } \quad \text { Vol. } & 2, \quad \text { No. } & 1, & \text { (2019). }\end{array}$ https://ujh.unja.ac.id/index.php/home/article/view/66.

\section{Website}

https://id.wikipedia.org/wiki/kedudukan hukum di Makamah Konstitusi/Diakses pada tanggal 09 November 2019. 
http://ngobrolinhukum.wordperss.com/2013/12/2016/pendekatan dalam penelitian hukum. Diakses pada tanggal 25 November 2019.

http://lib.ui.ac.id/file?file=digital/20315934-T31500-Tinjauan\%20teoritis.pdf. Diakses pada tanggal 13 Februari 2020.

https://www.kompas.com/tren/read/2020/01/18/213315465/selain kakek sa mirin ini 4 kasus hukum yang sempat menimpa lansia?page=all\#page4. Diakses pada tanggal 15 Februari 2020. 